\title{
Predictors of adverse maternal and perinatal outcomes in a refugee population from an active conflict country, Syria
}

\section{Suriyeli mülteci gebelerde maternal ve perinatal komplikasyonlarn belirleyicileri}

\author{
(1) Serap Fırtına Tuncer, (1) Burcu Timur, (1) Ethem Serdar Yalvaç, (1) Leyla Mollamahmutoğlu \\ University of Health Sciences, Etlik Zübeyde Hanım Women's Diseases Training and Research Hospital, Clinic of Obsttetrics and Gynecology, \\ Ankara, Turkey
}

\begin{abstract}
Objective: To elucidate predictors of adverse maternal and perinatal outcomes in refugees emigrating from an active conflict region (Syria).

Materials and Methods: This study included Syrian pregnant women who gave birth in Etlik Zübeyde Hanım Training and Research Hospital between 2013 and 2016. Adverse perinatal outcomes were defined as preterm labor, premature rupture of membranes, early membrane rupture, intrauterine growth retardation, hypertension, perinatal excites, and erythrocyte-transfused cases. Factors associated with those adverse outcomes were assessed using multiple logistic regression analysis.

Results: Having an active smoking habit [odds ratio (OR): 2.647, 95\% confidence interval (CI): 1.767-3.965; p<0.001], obesity (OR: 2.272, 95\% CI: 1.396-3.699; $\mathrm{p}=0.001$ ), and adolescent age (OR: 1.732, 95\% CI: 1.204-2.491; $\mathrm{p}=0.003$ ) were found to be the most important predictors of adverse maternal and perinatal outcomes. Eighty of 129 (62\%) smokers, 45 of 81 (55.65\%) obese individuals, and 91 of 169 adolescents (53.8\%) had adverse maternal and perinatal outcomes. Conclusion: Prevention strategies for obesity, smoking, and adolescent pregnancies should be implemented primarily to reduce maternal and antenatal adverse outcomes. Pregnant women with these risk factors in a refugee community emigrating from a conflict-zone nation should be followed up closely.

Keywords: Refugees, Syrian, immigrants, pregnancy, perinatal outcome, maternal outcome

Öz

Amaç: Suriyeli mülteci gebelerde maternal ve perinatal komplikasyonlara etki eden faktörleri belirlemeyi amaçladık.

Gereç ve Yöntemler: Etlik Zübeyde Hanım Kadın Hastalıklan Eğitim ve Araştırma Hastanesi’nde 2013-2016 yllarında doğum yapmış Suriyeli gebeler çalışma kapsamında değerlendirilmiştir. Maternal ve perinatal komplikasyonlar; preterm eylem, preterm erken membrane rüptürü, erken membrane rüptürü, intrauterin büyüme kısıtllı̆̆ı, hipertansiyon, perinatal ölüm ve kan transfüzyonu yapılması olarak tanımlanmıştır. Bu komplikasyonlara etki eden faktörler çoklu regresyon analizi ile değerlendirilmişlerdir.

Bulgular: Sigara kullanmak [olasıllk oranı (OR): 2,647, \%95 güven aralığı (CI): 1,767-3,965; p<0,001], obezite (OR: 2,272, 95\% CI: 1,396-3,699; p=0,001), adölesan gebelik (OR: 1,732, 95\% CI: 1,204-2,491; p=0,003) maternal ve perinatal komplikasyonların en önemli belirleyicileridir. Sigara kullanan gebelerin \%62'si (80/129), obez gebelerin \%55,65'I (45/81), adölesan gebelerin \%53,8`i (53,8\%) maternal ve perinatal komplikasyonlar ile birliktedir.

Sonuç: Maternal ve perinatal komplikasyonların önlenmesi amacıyla gebelikte obezite, sigara kullanımı ve adolesan gebeliklerin önlenmesi amaçlanmalıdır. Bu belirleyicilerle birlikte olan mülteci kadınlar düzenli takip edilmelidir.

Anahtar Kelimeler: Mülteci, Suriyeli, göçmen, gebelik, perinatal sonuç, maternal sonuç

\section{Introduction}

Refugees, especially those emigrating from their home country due to war or other hardships, face many difficulties in their new host countries. Changes in food consumption, economic difficulties, language barriers, and limitations in accessing

healthcare may disturb their health-related conditions ${ }^{(1-3)}$. Being a vulnerable group, immigrant pregnant women in particular experience more difficulties and perhaps may have more adverse outcomes. Since March 2011, the Turkish government has begun hosting millions of Syrian refugees, preparing refugee
\end{abstract}

PRECIS: Smoking, obesity, and adolescence are the most important predictors for adverse maternal and perinatal outcomes in pregnant refugees.

Address for Correspondence/Yazışma Adresi: Serap Fırtına Tuncer, MD,

University of Health Sciences, Etlik Zübeyde Hanım Women's Diseases Training and Research Hospital, Clinic of Obstetrics and Gynecology, Ankara, Turkey

Phone: +90 5056889637 E-mail: drserap.firtina@hotmail.com ORCID ID: orcid.org/0000-0001-8976-0978

Received/Gelis Tarihi: 31.05.2019 Accepted/Kabul Tarihi: 23.07.2019

${ }^{\oplus}$ Copyright 2019 by Turkish Society of Obstetrics and Gynecology

Turkish Journal of Obstetrics and Gynecology published by Galenos Publishing House. 
camps and giving them the opportunity to travel to all cities of the country. At present, more than 3.5 million Syrian refugees are scattered all around Turkey ${ }^{(4)}$. According to the United Nations Refugee Agency, Turkey is the most accessed hosting country for refugees worldwide ${ }^{(4)}$. Previous studies have shown an increased risk of adverse maternal and perinatal outcomes for emigrating pregnant women including maternal anemia, preterm birth, low birth weight, bleeding during delivery, psychological distress, perineal laceration, and postpartum hemorrhage ${ }^{(1-3,5-7)}$. Besides these data, pregnant women leaving conflict regions have increased adverse perinatal complications as compared with pregnant women from non-conflict regions ${ }^{(8,9)}$. A pregnant refugee's country of origin is found to be an important predictor of pregnancy outcomes. Moreover, immigration itself has a negative impact on pregnancy outcomes in the same nation ${ }^{(10,11)}$.

Predictors of adverse events in pregnancy in among women emigrating from a nation in an active conflict region have not been well studied to date. Therefore, in the present study, we sought to identify predictors of adverse maternal and perinatal outcomes in refugees coming from an active conflict region, specifically Syria.

\section{Materials and Methods}

\section{Study design}

The maternity clinic at Etlik Zübeyde Hanım Training and Research Hospital is a tertiary maternity unit with a neonatal intensive care unit (NICU). Most patients seen here, including both refugees and Turkish people, are referred from other clinics when gestational and fetal complications are suspected. For this study, we employed a Syrian interpreter to communicate with the refugees. After approval of the study protocol by our institutional review board, the files and birth records of Syrian refugees concerning the period 2013 through 2016 were retrospectively analyzed. As the Turkish government provided a translator, hospital staff and medical team communicated with the patients with the help of a translator or relatives speaking Turkish. To establish a high-quality dataset, only parameters of singleton pregnancies with complete data were included. Parameters including gestational diabetes mellitus and systemic disorders were not included in the analysis because the refugee population had poor antenatal care. All patients were evaluated using ultrasonography at the time of delivery and according to need at each other visit. Demographic data including maternal age, gravidity, parity, smoking habits, history of abortion, route of delivery in previous births, gestational age at delivery, number of antenatal follow-ups, mode of delivery, and maternal hemoglobin $(\mathrm{Hb})$ levels were extracted. Patients' body mass index (BMIs) were calculated based on their height and body weight at the time of admission to hospital for delivery. Obese patients were defined as those with BMI values equal to or greater than $30 \mathrm{~kg} / \mathrm{m}^{2}$. Adverse perinatal outcomes were defined as preterm labor, premature rupture of membranes (PPROM), early membrane rupture (EMR), intrauterine growth retardation (IUGR), hypertension, perinatal exitus, and erythrocyte-transfused cases. The newborn's birth weight, one and five-minute Apgar scores, heart pulse rates, grimace response, activity, respiration scores, admission to the NICU were recorded. Gestational age was determined based on the first day of the last menstruation period (LMP) of the mother. For patients who did not know their LMP, gestational age was calculated based on their earliest obstetric ultrasound. Hypertension during pregnancy was defined as a blood pressure of more than $140 / 90 \mathrm{mmHg}$ measured on two occasions. Preterm delivery was defined as birth before 37 weeks, and IUGR was determined based on clinical evaluation and ultrasonographic parameters. Adolescent pregnancy was noted when the patient was younger than 20 years of age at the time of delivery.

\section{Statistical Analysis}

The Statistical Package for the Social Sciences version 23.0 for Windows (IBM Corp., Armonk, NY, USA) software package was used and $p$ values less than 0.05 were defined as statistically significant. Variables with p values less than 0.1 on univariate analysis were included in binominal logistic regression analysis.

\section{Results}

A total of 747 pregnant Syrian refugees had deliveries between 2013 and 2016. Eight twin pregnancies and 35 patients with incomplete data were excluded from this study. Therefore, a total of 698 Syrian refugees were included in the present study, including 167 adolescents (23.9\%) aged between 12 and 19 years. The clinical characteristics of the study population are presented in Table 1 . The median age of the study participants was 24 years, and the majority (67.2\%) were multigravida. Most patients ( $\mathrm{n}=370)$ had visits only during the third trimester (53.0\%), and only 220 (31.5\%) patients had four or more antenatal visits. Adverse maternal and perinatal outcomes were present in $306(43.8 \%)$ cases. In 83 patients, multiple adverse maternal and/or perinatal outcomes were recorded as follows: preterm labor was observed in 134, IUGR in 86, and PPROM or EMR in 81, respectively. Additionally, gestational hypertension in two out of 11 women resulted in ablatio placenta, intrauterine exitus was seen in seven, neonatal exitus was observed in eight, and severe maternal anemia requiring erythrocyte transfusion was present in 45 women (Table 2). Table 3 demonstrates the relationship between adverse maternal-fetal outcomes and possible risk factors. Adolescent pregnancy $(\mathrm{p}=0.003)$, being a smoker $(p<0.001)$, obesity $(p=0.024)$, and a number of antenatal visits of less than four $(p<0.001)$ were related with adverse maternal and fetal outcomes.

\section{Results of logistic regression analysis}

The probability of adverse maternal and perinatal outcomes increased 2.647 times [95\% confidence interval (CI) for odds 
ratio (OR): 1.767-3.965] in smokers when compared with nonsmokers $(\mathrm{p}<0.001)$. Obesity $\left(\mathrm{BMI}>30 \mathrm{~kg} / \mathrm{m}^{2}\right)$ increased the probability of adverse maternal-fetal outcomes 2.272 times (95\% CI for OR: 1.396-3.699) relative to patients with BMIs of $30 \mathrm{k} /$ $\mathrm{m}^{2}$ or less ( $\left.\mathrm{p}=0.001\right)$. Also, the probability of adverse maternalfetal outcomes increased 1.732 times (95\% CI for OR: 1.2042.491) in adolescent pregnant women in comparison with adult pregnant women $(\mathrm{p}=0.03)$. In the regression analysis, gravidity

Table 1. Characteristics of study population

\begin{tabular}{|c|c|c|}
\hline Characteristic & Parameters & Values (\%) \\
\hline Age (years) & $\begin{array}{l}\text { Median } \\
25^{\text {th }}-75^{\text {th }} \text { percentiles }\end{array}$ & $\begin{array}{l}24 \\
20-28.25\end{array}$ \\
\hline Gravidity & $\begin{array}{l}\text { Median } \\
25^{\text {th }}-75^{\text {th }} \text { percentiles }\end{array}$ & $\begin{array}{l}2 \\
1-3\end{array}$ \\
\hline Parity & $\begin{array}{l}\text { Median } \\
25^{\text {th }}-75^{\text {th }} \text { percentiles } \\
\text { Nullipar } \\
\geq 1\end{array}$ & $\begin{array}{l}1 \\
0-2 \\
283(41.1) \\
406(58.9)\end{array}$ \\
\hline Age group & $\begin{array}{l}\text { Adolescent } \\
\text { Adult }\end{array}$ & $\begin{array}{l}167(23.9) \\
531(76.1)\end{array}$ \\
\hline Smoking habitus & $\begin{array}{l}\text { Non-smoker } \\
\text { Smoker }\end{array}$ & $\begin{array}{l}565(80.9) \\
133(19.1)\end{array}$ \\
\hline Abortus history & $\begin{array}{l}+ \\
-\end{array}$ & $\begin{array}{l}94(13.5) \\
604(86.5)\end{array}$ \\
\hline Previous cesarean & $\begin{array}{l}+ \\
-\end{array}$ & $\begin{array}{l}104(14.9) \\
594(85.1)\end{array}$ \\
\hline BMI & $\begin{array}{l}\text { Median } \\
25^{\text {th }}-75^{\text {th }} \text { percentiles }\end{array}$ & $\begin{array}{l}26.6 \\
24.3-28.3\end{array}$ \\
\hline Maternal $\mathrm{Hb}$ & $\begin{array}{l}\text { Median } \\
25^{\text {th }}-75^{\text {th }} \text { percentiles }\end{array}$ & $\begin{array}{l}11.15 \\
10.10-12.10\end{array}$ \\
\hline Birth week & $\begin{array}{l}\text { Median } \\
25^{\text {th }}-75^{\text {th }} \text { percentiles }\end{array}$ & $\begin{array}{l}37 \\
36-39\end{array}$ \\
\hline Fetal body weight & $\begin{array}{l}\text { Median } \\
25^{\text {th }}-75^{\text {th }} \text { percentiles }\end{array}$ & $\begin{array}{l}3060 \\
2720-3380\end{array}$ \\
\hline $\begin{array}{l}\text { Apgar score } \\
\left(1^{\mathrm{st}} \mathrm{m}\right)\end{array}$ & $\begin{array}{l}\text { Median } \\
25^{\text {th }}-75^{\text {th }} \text { percentiles }\end{array}$ & $\begin{array}{l}9 \\
9-9\end{array}$ \\
\hline $\begin{array}{l}\text { Apgar score } \\
\left(5^{\text {th }} \mathrm{m}\right)\end{array}$ & $\begin{array}{l}\text { Median } \\
25^{\text {th }}-75^{\text {th }} \text { percentiles }\end{array}$ & $\begin{array}{l}10 \\
9-10\end{array}$ \\
\hline $\begin{array}{l}\text { Antenatal } \\
\text { follow-up }\end{array}$ & $\begin{array}{l}\geq 4 \\
<4\end{array}$ & $\begin{array}{l}217(31.1) \\
481(68.9)\end{array}$ \\
\hline Mode of delivery & $\begin{array}{l}\text { Vaginal birth } \\
\text { Cesarean }\end{array}$ & $\begin{array}{l}439(62.9) \\
259(37.1)\end{array}$ \\
\hline Maternal transfusion & + & $\begin{array}{l}80(11.5) \\
618(88.5)\end{array}$ \\
\hline Neonatal intensive care & + & $\begin{array}{l}83(11.9) \\
615(88.1)\end{array}$ \\
\hline $\begin{array}{l}\text { Adverse maternal fetal } \\
\text { outcome }\end{array}$ & + & $\begin{array}{l}306(43.8) \\
392(56.2)\end{array}$ \\
\hline
\end{tabular}

BMI: Body mass index, Hb: Hemoglobin of more than two and less than four antenatal visits were not significant indicators of adverse maternal-fetal outcomes (Table 4). Correlations between the detected risk factors and each adverse maternal or perinatal outcome are presented in Table 5. Maternal anemia requiring erythrocyte transfusion was found as a more common feature of nonsmoking pregnant women versus those with an active smoking habit $(\mathrm{p}=0.008)$. Preterm birth ( $\mathrm{p}=0.022)$, PPROM or EMR $(\mathrm{p}<0.001)$, IUGR $(\mathrm{p}<0.001)$, and perinatal exitus $(\mathrm{p}<0.001)$ were more commonly observed in smokers than in nonsmokers. PPROM or EMR ( $\mathrm{p}=0.039)$ and hypertension $(\mathrm{p}=0.009)$ were additionally found more

Table 2. Number of adverse maternal and perinatal outcomes

\begin{tabular}{ll} 
Adverse perinatal outcomes & n \\
\hline Preterm labor & 134 \\
\hline IUGR & 86 \\
\hline PPROM/EMR & 81 \\
\hline Hypertension & 17 \\
\hline Perinatal exitus & 15 \\
\hline Maternal transfusion & 56 \\
Total & 389
\end{tabular}

PPROM: Premature rupture of membranes, EMR: Early membrane rupture, IUGR: Intrauterine growth retardation

Table 3. Relationship between adverse maternal perinatal outcome and possible risk factors

\begin{tabular}{|c|c|c|c|c|}
\hline \multirow[t]{2}{*}{ Characteristics } & \multirow[t]{2}{*}{ Parameters } & \multicolumn{2}{|c|}{$\begin{array}{l}\text { Adverse maternal fetal } \\
\text { outcome }\end{array}$} & \multirow{2}{*}{$\begin{array}{l}\text { Univariate } \\
\text { analysis } \\
\text { p value }\end{array}$} \\
\hline & & + & - & \\
\hline Age (years) & $\begin{array}{l}\leq 24 \\
>24\end{array}$ & $\begin{array}{l}177(46.6) \\
129(40.6)\end{array}$ & $\begin{array}{l}203(53.4) \\
189(59.4)\end{array}$ & 0.111 \\
\hline Gravidity & $\begin{array}{l}\leq 2 \\
>2\end{array}$ & $\begin{array}{l}202(47.5) \\
169(61.9)\end{array}$ & $\begin{array}{l}223(52.5) \\
104(38.1)\end{array}$ & 0.014 \\
\hline Parity & $\begin{array}{l}\text { Nullipar } \\
\geq 1\end{array}$ & $\begin{array}{l}146(50.0) \\
160(39.4)\end{array}$ & $\begin{array}{l}146(50.0) \\
246(60.6)\end{array}$ & 0.005 \\
\hline Adolescent & $\begin{array}{l}+ \\
-\end{array}$ & $\begin{array}{l}91(53.8) \\
215(40.6)\end{array}$ & $\begin{array}{l}78(46.2) \\
314(59.4)\end{array}$ & 0.003 \\
\hline $\begin{array}{l}\text { Previous } \\
\text { cesarean }\end{array}$ & $\begin{array}{l}+ \\
-\end{array}$ & $\begin{array}{l}41(39.8) \\
265(44.5)\end{array}$ & $\begin{array}{l}62(60.2) \\
330(55.5)\end{array}$ & 0.372 \\
\hline $\begin{array}{l}\text { Smoking } \\
\text { habitus }\end{array}$ & $\begin{array}{l}\text { Smoker } \\
\text { Non- } \\
\text { smoker }\end{array}$ & $\begin{array}{l}80(62.0) \\
226(39.7)\end{array}$ & $\begin{array}{l}49(38.0) \\
343(60.3)\end{array}$ & $<0.001$ \\
\hline $\begin{array}{l}\text { Abortus } \\
\text { history }\end{array}$ & + & $\begin{array}{l}36(38.7) \\
270(44.6)\end{array}$ & $\begin{array}{l}57(61.3) \\
335(55.4)\end{array}$ & 0.284 \\
\hline BMI & $\begin{array}{l}\text { Obese } \\
\text { Non-obese }\end{array}$ & $\begin{array}{l}45(55.6) \\
261(42.3)\end{array}$ & $\begin{array}{l}36(44.4) \\
356(57.7)\end{array}$ & 0.024 \\
\hline $\begin{array}{l}\text { Antenatal } \\
\text { visits }\end{array}$ & $\begin{array}{l}<4 \\
\geq 4\end{array}$ & $\begin{array}{l}229(48.6) \\
77(33.9)\end{array}$ & $\begin{array}{l}242(51.4) \\
105(46.3)\end{array}$ & $<0.001$ \\
\hline
\end{tabular}

BMI: Body mass index 
commonly in obese patients versus non-obese patients. Lastly, preterm birth $(\mathrm{p}=0.018)$ and IUGR $(\mathrm{p}<0.001)$ were more commonly observed in adolescent pregnant women than in adult pregnant women.

\section{Discussion}

This study showed that an active smoking habit [OR: 2.647, 95\% CI: (1.767-3.965 9); p<0.001], obesity [OR: 2.272, 95\% CI: (1.396-3.699); $\mathrm{p}=0.001]$, and adolescence [OR: 1.732, 95\% CI: (1.204-2.491); $\mathrm{p}=0.003$ ] were the most important predictors for adverse perinatal outcomes of pregnant women emigrating from an active war region. Eighty of 129 (62\%) smokers, 45 of 81 (55.65\%) obese individuals (BMI $>30 \mathrm{~kg} / \mathrm{m}^{2}$ ), and 91 of 169 (53.8\%) adolescent pregnant women had any one of the following adverse maternal and perinatal outcomes: preterm birth, PPROM, EMR, IUGR, hypertension, a need for erythrocyte transfusion or perinatal exitus. As compared with nonsmokers, smoking during pregnancy increased the risks of preterm birth [OR: 2.6, 95\% CI: (1.1-1.6) for >10 cigarettes/ day], and PPROM [OR: 1.97, 95\% CI: (1.32-2.94) for $>10$ cigarettes/day] depending on the pack/years of smoking(12,13). A meta-analysis of 46 studies documented that any amount of smoking increased the risk of perinatal death (OR: 1.33, 95\% CI: 1.25-1.41 ${ }^{(14)}$. Besides, smoking had a negative impact on fetal growth and increased the risk of IUGR (OR: 2.07, 95\% CI: $1.69 \pm 2.53)^{(15)}$. In accordance with previous studies, we found that, even in a migrant population, smoking increased the risks of preterm birth, PPROM, IUGR, and perinatal death (Table 4). It was reported that anemia is not a generalized sign, and elevated $\mathrm{Hb}$ levels were detected in smokers ${ }^{(16)}$. Accordingly, we found that a need for blood transfusion for anemia was more frequent among nonsmokers in the refugee population. Obesity is the principle health problem that causes adverse effects in pregnancy ${ }^{(17)}$. Obesity is related with various adverse obstetric complications such as gestational diabetes mellitus, hypertension, venous thromboembolism, shoulder dystocia, prematurity, stillbirth, neonatal death, postpartum hemorrhage, and urinary, uterine, and wound infections ${ }^{(18)}$. A prevalence rate of $46.4 \%$ was reported in a study among Syrian women in $2006^{(19)}$. In the present study of refugee women, we found obesity at a rate of $11.6 \%$, which is significantly lower than that reported in the literature. This may be explained by the negative impact of war on adequate nutrition and its related factors (e.g., difficulty in reaching food, low socioeconomic levels, and

Table 4. Logistic regression results of the risk factors for adverse maternal and fetal outcomes

\begin{tabular}{|c|c|c|c|c|c|c|c|c|}
\hline & Coefficient & SE & Wald & df & $\mathrm{p}$ & OR & \multicolumn{2}{|c|}{ 95\% CI for OR } \\
\hline Smoking & 0.973 & 0.206 & 22.277 & 1 & $<0.001$ & 2.647 & 1.767 & 3.965 \\
\hline BMI & 0.821 & 0.249 & 10.899 & 1 & 0.001 & 2.272 & 1.396 & 3.699 \\
\hline Adolescent pregnancy & 0.549 & 0.185 & 8.768 & 1 & 0.003 & 1.732 & 1.204 & 2.491 \\
\hline
\end{tabular}

SE: Standard error, df: Degrees of freedom, OR: Odds ratio, CI: Confidence interval, BMI: Body mass index

Hosmer and Lemeshow test value: 0.998, Nagelkerke R square test value: 0.096, Sensitivity: 46\%, specificity: 74\%

Table 5. Relationship between risk factors and adverse maternal-perinatal outcomes

\begin{tabular}{|c|c|c|c|c|c|c|c|c|c|c|}
\hline \multirow{2}{*}{\multicolumn{2}{|c|}{$\begin{array}{l}\text { Adverse maternal-fetal } \\
\text { outcomes }\end{array}$}} & \multicolumn{2}{|l|}{ Smoking } & \multirow[t]{2}{*}{$\mathrm{p}$} & \multicolumn{2}{|l|}{ BMI } & \multirow[t]{2}{*}{$\mathrm{p}$} & \multicolumn{2}{|c|}{ Adolescent pregnancy } & \multirow[t]{2}{*}{$\mathrm{p}$} \\
\hline & & + & - & & $\leq 30$ & $>30$ & & + & - & \\
\hline Preterm birth & $\begin{array}{l}+ \\
-\end{array}$ & $\begin{array}{l}34(26.4) \\
95(73.6)\end{array}$ & $\begin{array}{l}100(17.6) \\
469(82.4)\end{array}$ & 0.022 & $\begin{array}{l}14(17.3) \\
67(82.7)\end{array}$ & $\begin{array}{l}120(19.4) \\
497(80.6)\end{array}$ & 0.642 & $\begin{array}{l}43(25.4) \\
126(74.6)\end{array}$ & $\begin{array}{l}91(17.2) \\
438(82.8)\end{array}$ & 0.018 \\
\hline PPROM, EMR & $\begin{array}{l}+ \\
-\end{array}$ & $\begin{array}{l}42(32.6) \\
87(67.4)\end{array}$ & $\begin{array}{l}39(6.9) \\
530(93.1)\end{array}$ & $<0.001$ & $\begin{array}{l}15(18.5) \\
66(81.5)\end{array}$ & $\begin{array}{l}66(10.7) \\
551(89.3)\end{array}$ & 0.039 & $\begin{array}{l}23(13.6) \\
146(86.4)\end{array}$ & $\begin{array}{l}58(11.0) \\
471(89.0)\end{array}$ & 0.350 \\
\hline IUGR & $\begin{array}{l}+ \\
-\end{array}$ & $\begin{array}{l}37(28.7) \\
92(71.3)\end{array}$ & $\begin{array}{l}49(8.6) \\
520(91.4)\end{array}$ & $<0.001$ & $\begin{array}{l}6(7.4) \\
75(92.6)\end{array}$ & $\begin{array}{l}80(13.0) \\
537(80.0)\end{array}$ & 0.152 & $\begin{array}{l}37(21.9) \\
132(78.1)\end{array}$ & $\begin{array}{l}49(9.3) \\
480(90.7)\end{array}$ & $<0.001$ \\
\hline Hypertension & $\begin{array}{l}+ \\
-\end{array}$ & $\begin{array}{l}2(1.6) \\
127(98.4)\end{array}$ & $\begin{array}{l}15(2.6) \\
554(97.4)\end{array}$ & 0.751 & $\begin{array}{l}6(7.4) \\
75(92.6)\end{array}$ & $\begin{array}{l}11(1.8) \\
606(98.2)\end{array}$ & 0.009 & $\begin{array}{l}6(3.6) \\
163(96.4)\end{array}$ & $\begin{array}{l}11(2.1) \\
518(97.9)\end{array}$ & 0.264 \\
\hline Maternal transfusion & + & $\begin{array}{l}3(2.3) \\
126(97.7)\end{array}$ & $\begin{array}{l}53(9.3) \\
516(90.7)\end{array}$ & 0.008 & $\begin{array}{l}10(12.3) \\
71(87.7)\end{array}$ & $\begin{array}{l}46(7.5) \\
571(92.5)\end{array}$ & 0.128 & $\begin{array}{l}16(9.5) \\
153(90.5)\end{array}$ & $\begin{array}{l}40(7.6) \\
489(92.4)\end{array}$ & 0.427 \\
\hline Perinatal exitus & $\begin{array}{l}+ \\
-\end{array}$ & $\begin{array}{l}11(8.5) \\
1180(91.5)\end{array}$ & $\begin{array}{l}4(0.7) \\
565(99.3)\end{array}$ & $<0.001$ & $\begin{array}{l}0 \\
81(100)\end{array}$ & $\begin{array}{l}15(2.4) \\
602(97.6)\end{array}$ & 0.239 & $\begin{array}{l}4(2.4) \\
165(97.6)\end{array}$ & $\begin{array}{l}11(2.1) \\
518(97.9)\end{array}$ & 0.766 \\
\hline
\end{tabular}

PPROM: Premature rupture of membranes, EMR: Early membrane rupture, IUGR: Intrauterine growth retardation, BMI: Body mass index 
increased psychological problems such as depression). In the present study, we found that obesity was not associated with idiopathic preterm birth; this finding was in accordance with the outcomes of a study of nearly 1.600 .000 deliveries in a population-based cohort study of women with live singleton births in Sweden ${ }^{(20)}$. Cnattingius et al. ${ }^{(20)}$ showed that obesity increased the incidence of preterm births, especially in the context of deliveries happening between 22 and 27 gestational weeks. In their study, the authors stated that obesity was related with preterm delivery because of PPROM and other obesityrelated diseases such as hypertension and diabetes; when these conditions were excluded, the preterm delivery risk was unchanged in obese patients ${ }^{(20)}$. Similarly, in a series of 4653 preterm births among more than 55.000 births, Madan et al. (21) also stated the adverse impact of diabetes and hypertension on the relationship between obesity and premature birth. In accordance with these prior studies, we found that obesity was not related with idiopathic preterm birth but was with hypertension and PPROM (Table 4). Indeed, Zhong et al. ${ }^{(22)}$ showed that obesity was associated with a decreased risk of spontaneous preterm birth without PPROM at less than 37 weeks' gestation (OR: 0.8, 95\% CI: 0.7-0.9) and increased risks of PPROM before 37 and 34 weeks' gestation [OR: 1.3, 95\% CI: (1.1-1.6) and OR: 1.4, 95\% CI: (1.0-2.0), respectively]. Adolescent pregnancy is one of the major health problems in refugee populations, resulting in adverse maternal-fetal outcomes. In a multinational study organized by the World Health Organization, Ganchimeg et al. ${ }^{(23)}$ documented more adverse maternal and adverse fetal outcomes among adolescent mothers (aged $\leq 20$ years) than among mothers aged 20 to 24 years. It is suggested that significantly younger adolescent mothers carry an especially higher risk of preterm delivery. In other words, mothers aged 15 years or younger are 1.6 times more likely to experience preterm delivery as compared with mothers aged 20 to 24 years (OR: 1.60, 95\% CI: 1.37-1.87). In the study by Ganchimeg et al. ${ }^{(23)} 11.2 \%$ of mothers aged 10 to 15 years, but only $7 \%$ of mothers aged 20 to 24 years had a risk of preterm delivery $(\mathrm{p}<0.001)$. In our study, we found that $25.4 \%$ of adolescent and $17.2 \%$ of adult mothers had a risk of preterm delivery ${ }^{(23)}$. Besides this, we also documented a higher risk of IUGR in the adolescent group (21.9\%) as compared with the adult group $(9.3 \%)(\mathrm{p}<0.001)$. Although we did not have the opportunity to compare the adult refugee population with an adolescent control group, we estimated higher risks of adverse maternal and perinatal outcomes in an adolescent refugee population as a result of the insufficient food supply, higher workloads, and malnutrition.

\section{Study Limitations}

There are some limitations to our study. Regression analysis results revealed $46 \%$ sensitivity and $74 \%$ specificity rates for the estimation of the risk of adverse maternal and perinatal outcomes. To increase the sensitivity and specificity of calculations, some other possible risk factors could be added to the study. However, this was a retrospective study, making it impossible to adequately evaluate all possible factors related to adverse outcomes in pregnancy. Additionally, our sample size was not large enough to be sufficiently powered to examine the relationship between possible risk factors and rates of pregnancy complications due to the low prevalence rates of stillbirth, preeclampsia, congenital anomalies, venous thromboembolism, and maternal death. Secondly, most of the patients in our series were referred from other clinics when a high-risk pregnancy complication was suspected, potentially introducing bias into the patient selection scheme for this study. Despite these limitations, our study is unique due to its evaluation of risk factors for adverse maternal and perinatal outcomes in a refugee population coming from an active conflict country. We believe that taking the results of this study into account could help in reducing adverse outcomes in pregnant refugee populations.

\section{Conclusion}

This study showed that smoking, obesity, and adolescence were the most important predictors for adverse maternal and perinatal outcomes in pregnant refugees coming from an active conflict region. Prevention strategies for obesity, smoking, and adolescent pregnancies should be implemented, primarily to reduce maternal and antenatal adverse outcomes. Additionally, pregnant women with these risk factors in a refugee communities emigrating from nations in conflict zones should be followed up closely.

\section{Ethics}

Ethics Committee Approval: Retrospective study. Informed Consent: Retrospective study. Peer-review: Externally peer-reviewed.

\section{Authorship Contributions}

Surgical and Medical Practices: E.S.Y.., S.F.T., B.T., L.M., Concept: E.S.Y.., S.F.T., B.T., L.M., Design: E.S.Y.., S.F.T., B.T., L.M., Data Collection or Processing: S.F.T., B.T., Analysis or Interpretation: E.S.Y.., S.F.T., B.T., L.M., Literature Search: S.F.T., Writing: S.F.T.

Conflict of Interest: No conflict of interest was declared by the authors.

Financial Disclosure: The authors declared that this study received no financial support.

\section{References}

1. Mangrio E, Sjögren Forss K. Refugees' experiences of healthcare in the host country: a scoping review. BMC Health Serv Res 2017; 17:814.

2. Alder J, Fink N, Lapaire O, Urech C, Meyer A, Bitzer J, et al. The effect of migration background on obstetric performance in Switzerland. Eur J Contracept Reprod Health Care 2008;13:103-8.

3. Lansakara N, Brown SJ, Gartland D. Birth outcomes, postpartum health and primary care contacts of immigrant mothers in an Australian nulliparous pregnancy cohort study. Matern Child Health J 2010;14:807-16. 
4. 4.The UN Refugee Agency (UNHCR). Figures at a glance. 2018. http://unhcr.org/figures-at-a-glance.html. Accessed 25.06.2018

5. Wanigaratne S, Cole DC, Bassil K, Hyman I, Moineddin R, Urquia ML. The influence of refugee status and secondary migration on preterm birth. J Epidemiol Community Health 2016;70:622-8.

6. Johnson EB, Reed SD, Hitti J, Batra M. Increased risk of adverse pregnancy outcome among Somali immigrants in Washington state. Am J Obstet Gynecol 2005;193:475-82.

7. Philibert M, Deneux-Tharaux C, Bouvier-Colle MH. Can excess maternal mortality among women of foreign nationality be explained by suboptimal obstetric care? BJOG 2008;115:1411-8.

8. Jamieson DJ, Meikle SF, Hillis SD, Mtsuko D, Mawji S, Duerr A. An evaluation of poor pregnancy outcomes among Burundian refugees in Tanzania. JAMA 2000;283:397-402.

9. Abu Hamad Kh, Abed Y, Abu Hamad B. Risk factors associated with preterm birth in the Gaza Strip: hospital-based case-control study. East Mediterr Health J 2007;13:1132-41.

10. Malin M, Gissler M. Maternal care and birth outcomes among ethnic minority women in Finland. BMC Public Health 2009;9:84.

11. Badshah S, Mason L, McKelvie K, Payne R, Lisboa PJ. Risk factors for low birthweight in the public-hospitals at Peshawar, NWFPPakistan. BMC Public Health 2008;8:197.

12. Kyrklund-Blomberg NB, Granath F, Cnattingius S. Maternal smoking and causes of very preterm birth. Acta Obstet Gynecol Scand 2005;84:572-77.

13. England MC, Benjamin A, Abenhaim HA. Increased risk of preterm premature rupture of membranes at early gestational ages among maternal cigarette smokers. Am J Perinatol 2013;30:821-6.

14. Pineles BL, Hsu S, Park E, Samet JM. Systematic Review and MetaAnalyses of Perinatal Death and Maternal Exposure to Tobacco Smoke During Pregnancy. Am J Epidemiol 2016; 184:87-97.
15. Horta BL, Victora CG, Menezes AM, Halpern R, Barros FC. Low birthweight, preterm births and intrauterine growth retardation in relation to maternal smoking. Paediatr Perinat Epidemiol 1997;11:140-51.

16. Nordenberg D, Yip R, Binkin NJ. The effect of cigarette smoking on hemoglobin levels and anemia screening. JAMA 1990;264:1556-9.

17. Flegal KM, Carroll MD, Kit BK, Ogden CL. Prevalence of obesity and trends in the distribution of body mass index among US adults, 1999-2010. JAMA 2012;307:491-7.

18. Fitzsimons KJ, Modder J, Greer IA. Obesity in pregnancy: risks and management. Obstet Med 2009;2:52-62.

19. Fouad M, Rastam S, Ward K, Maziak W. Prevalence of obesity and its associated factors in Aleppo, Syria. Prev Control 2006;2:85-94.

20. Cnattingius S, Villamor E, Johansson S, Edstedt Bonamy AK, Persson M, Wikström AK, et al. Maternal obesity and risk of preterm delivery. JAMA 2013;309:2362-70.

21. Madan J, Chen M, Goodman E, Davis J, Allan W, Dammann O. Maternal obesity, gestational hypertension, and preterm delivery. J Matern Fetal Neonatal Med 2010;23:82-8.

22. Zhong Y, Cahill AG, Macones GA, Zhu F, Odibo AO. The association between prepregnancy maternal body mass index and preterm delivery. Am J Perinatol 2010;27:293-8.

23. Ganchimeg T, Ota E, Morisaki N, Laopaiboon M, Lumbiganon P, Zhang J, et al. Pregnancy and childbirth outcomes among adolescent mothers: a World Health Organization multicountry study. BJOG 2014; 121 Suppl 1:40-8. 